\title{
農村地域住民のライフイベント，主観的健康感と 保健習慣との関連
}

\author{
直 島 淳 太, 福 永一 郎, 武田 則 昭, \\ 北 空 隆子, 實 成 文彦 \\ 香川医科大学人間環境医学講座衛生・公衆衛生学
}

\section{Association between Life Events, Subjective Health Status and Health Practices in a Rural Population}

\author{
Junta NAOSHIMA, Ichiro FUKUNAGA, Noriaki TAKEDA, Takako KITAMADO \\ and Fumihiko JITSUNARI \\ Department of Hygiene and Public Health, Faculty of Medicine, Kagawa Medical University, Kagawa
}

\begin{abstract}
A survey has been conducted on subjective health status, experience of life events in recent 1 year, and health practices in the rural of Kagawa prefecture. The survey was performed from March 1995 to May 1995 with 4,013 participants, aged 40 to less than 80.

The proportion of respondents who recognized their physical conditions as good decreased with age. However, the proportion of respondents who recognized their life satisfaction as good increased with age. 'Health-related' life events were the most common experienced life events for both male and female. The proportion of respondents who had life events of type 'family', 'financial', 'at workplace or job', 'in the community', and 'others' decreased with age. Men had higher proportion of 'at workplace or job' life events.

The higher proportion of respondents who experienced life events recognized their subjective health status poor. For male, it observed that poor physical health status had significant association with experience of type 'in the community' and 'environmental' life events. Poor mental health status significantly associated with experience of type 'at workplace and job' life events for male, and with 'health-related' and 'family' life events for female. Poor life satisfaction significantly associated with 'at workplace or job' and 'in the community' life events for male, and with 'health related' and 'family' life events.

Higher proportion of the respondents who experienced life events and recognized their subjective health status poor had low health practice scores. Logistic regression analysis showed that experience of life events and poor subjective health status had significant association with the poor health practices, especially with 'body weight changed' for both male and female.
\end{abstract}

Key words: life event（ライフイベント), subjective health status（主観的健康感）, health practice（保健習慣), stress（ストレス）

緒言

WHO はその憲章において,「健康」を「身体的・精神 的・社会的に完全に良好な状態」と定義した。これは，

受付 2000 年 11 月 29 日, 受理 2001 年 2 月 19 日

Reprints requests to: Junta NAOSHIMA

Department of Hygiene and Public Health, Faculty of Medicine, Kagawa Medical University, Kagawa

TEL: +81(87)891-2133, FAX: +81(87)891-2134
健康という事象が単に疾病がない状態を表すのではな く, 社会生活を営む人間存在の基本的な条件としてとら えたものである。

医学的なデータと基準に基づいて客観的に測定される 「健康な状態」（客観的健康）とは，生命維持や身体的機 能・精神的機能の保持増進にかかわる重大な疾病がな いこと，あるいは起こる可能性がないことである。一方 で，主観に基づいて個人が自分で「健康である」と認識 する ${ }^{1)}$ 健康評価が存在し，主観的健康感と呼ばれてい 
る。

先行研究では, 主観的健康感が高齢者の客観的健康 評価と関連を有する場合があるが，その関連の強弱は回 答者のライフステージ・環境的要因などによって異なっ ていたという知見が得られている ${ }^{2,3)}$ 。また，高齢者に おける主観的健康感が将来の死亡リスクと関連を有す

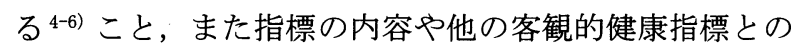
併用によっては, 高齢者における QOL の予後予測に資す る可能性を持った指標である，という知見も得られてい る $^{7,8)}$ 。

予防医学の進展に伴い，生活習慣病の予防は，わが国 の保健政策において重要な位置をしめている。しかし, 生活習慣病の予防に有効とされる保健習慣と, 主観的健 康感の関連について検討された例9) は少ない。また，主 観的健康感はライフイベント ${ }^{10)}$ の経験によって影響を 受けることがあるという知見が得られている ${ }^{11)}$ が，これ らが保健習慣に対して相互にどのような影響を及ぼして いるかという点については明らかにされていない。

そこで本研究では，調査対象となることの少ない，幅 広い年齢層の地域住民を対象とする悉皆調査を行い, ラ イフイベントと主観的健康感の関連や，保健習慣に対す るそれらの影響について検討を試みた。

\section{対象と方法}

\section{（1）調査対象地域}

調查対象地域は, 香川県の県庁所在地から南西約 $20 \mathrm{~km}$ に位置する A 町である。人口約 7,000人のこの町 は, 古くから米作地帯として知られ，酒造業でも知られ る農村地域である。就業者人口の約 3 割が農林業に従事 しているが，近隣の市や県庁所在地等の市街地域に勤務 先を有する者も多い。医療施設は診療所のみであり, 病 院や老人保健施設等の入所施設は設置されていない。医 療機関を受診する場合は近隣の市町へ行く者も多い。し かし，健診をはじめとする地域保健活動は活発である。 基本健康診査の受診率は調査年（平成 7 年）前後におい て 50 〜 60\%程度である。

\section{(2) 調查対象}

調查対象は, $\mathrm{A}$ 町内に在住する 40 歳以上 80 歳未満の 全住民である。調查は自記式質問紙による留め置き法 とした。調查票の配布と回収は, 平成 7 年 3 月から 5 月 にかけて，主に自治会経由で行われた。対象者総数は 4,013 名, 調查票の回収数は 3, 242 名（男性 1,546名, 女 性 1,696 名), 回収率 $80.8 \%$ であったが, 本研究におけ る解析対象者は, 解析に用いた全ての質問項目に回答し た者のみとした。その人数は 2, 464 名（男性 1,215 名, 女性 1,249 名）であり, 対象者総数に対する有効回答率 は $61.4 \%$ であった。

\section{(3) 調査内容}

1）最近 1 年間のライフイベント（日常生活における 「できごと」）の有無（Table 1)

最近 1 年間の生活における「できごと」として,「健康 上 Health-related $\rfloor$,「家族関係 Family」,「経済上 Financial」,「仕事上 At workplace or job」,「近所づきあいや地 域の In the community」,「騒音や悪臭など環境上 Environmental」および「その他 Others」の7 項目について, それぞれの有無を質問した。

\section{2) 現在の主観的健康感 (Table 1)}

現在の自分の健康状態への自己評価を，身体的健康 感, 精神的健康感, 日常生活における生きがい感の有無, の 3 項目で質問した。これらの項目は主観的健康感や人 生における生きがい感，幸福感等に関する先行研究 ${ }^{10,12)}$

Table 1 Questionnaire for life events, subjective health status and health practices

現在のあなたの生活（日頃）についておたずねします。 ・睡眠時間は何時間ですか。
1. 6 時間以下
2. $7 \sim 8$ 時間
3. 9 時間以上

・朝食は毎朝食べていますか。

$$
\text { 1.はい 2. いいえ }
$$

・体重の変化はありますか。
1. ほとんど変化なし
2. 増えた
3. 減った

・間食は毎日とりますか。

1.はい 2. いいえ

・何か運動をしていますか。

[スポーツとは, テニス, 水泳, ジョギングなど, 軽い運動

とは, 散歩, ラジオ体操, ゲートボールなどを意味します。

1. スポーツを週に 3 回以上する

2. スポーツを週に 1,2 回する

3. 軽い運動を週に 3 回以上する

4. 軽い運動を週に 1, 2 回する

5. 何もやらない

お酒はどのくらい飲みますか。

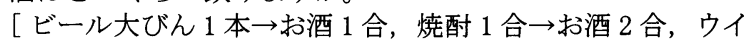

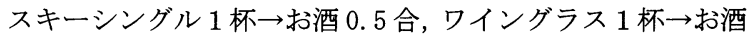
0.5 合と考えてください。]

1. 飲まない 2. たまに飲む

3. 毎日飲む $\langle 1 \sim 2$ 合〉 4 . 毎日飲む〈3 合以上〉

たばこは 1 日平均どのくらい吸いますか。

1. 吸ったことがない 2. ときどき吸う

3. 以前に吸ったことがある〈20 本未満〉

4. 以前に吸ったことがある〈20 本以上〉

5. 毎日吸 う〈20本未満〉 6. 毎日吸う〈20本以上 あなたはご自身の肉体的な健康状態をどう思いますか。
1. 健康
2. まあ健康
3. 病気がち
4. 病気

あなたはご自身の精神的な健康状態をどう思いますか。
1.よい
2. まあよい
3. やや悪い
4. 悪い

生きがいのある生活をしていますか。

1.はい 2. いいえ

この一年間に, あなたの生活上で生じたできごとについておた

ずねします。

・健康上のできごとはありましたか。

・家族関係のできごとはありましたか。

・経済上のできごとはありましたか。

1. 有

1. 有

2. 無

・仕事上のできごとはありましたか。

・近所づきあいや地域でのできごと。

・騒音や悪臭など環境上のできごと。

・その他のできごとはありましたか。

1. 有 2. 無

1. 有 2. 無

1. 有 2 . 無

1. 有 2 , 無

1. 有 2. 無


Table 2 The health practices

1. Having breakfasted everyday

2. Rarely eating between meals

3. Sleeping $7-8$ hours a day

4. Being near or at prescribed weight

5. Regular exercise

6. Having moderate or no use of alcohol

7. Not smoking
をもとに設定した。身体的健康感は「健康」,「まあ健 康」,「病気がち」および「病気」の, 精神的健康感は「良 い,「まあ良い」，「やや悪い」および「悪い」の 4 段階 尺度でそれぞれ質問した。これらの項目については，集 計の際に 4 カテゴリーを 2 カテゴリーに併合し，「良好 群 good」,「不良群 poor」の 2 グループとした。その内 容は以下のとおりである。なお, 日常生活における生き がい感（以下，「生きがい感」という）の有無について は,「ある」としたものを良好群,「なし」としたものを

Table 3 Number of persons who experienced life events in recent 1 year

\begin{tabular}{|c|c|c|c|c|}
\hline Life events & & Total $(n=2,464)$ & Male $(n=1,215)$ & Female $(n=1,249)$ \\
\hline \multirow[t]{6}{*}{ Health-related } & total & $627(25.4 \%)$ & $274(22.6 \%)$ & $353(28.3 \%)$ \\
\hline & $40 \sim 49$ age group & $206(25.7 \%)$ & $288(21.4 \%)$ & $118(30.3 \%)$ \\
\hline & $50 \sim 59$ age group & $135(25.2 \%)$ & $57(21.6 \%)$ & $78(28.8 \%)$ \\
\hline & $60 \sim 69$ age group & $153(22.4 \%)$ & $70(21.0 \%)$ & $83(23.7 \%)$ \\
\hline & $70 \sim 79$ age group & $133(30.0 \%)$ & $59(28.6 \%)$ & $74(31.1 \%)$ \\
\hline & & $\mathrm{p}=0.4826$ & $\mathrm{p}=0.1280$ & $\mathrm{p}=0.5630$ \\
\hline \multirow[t]{6}{*}{ Family } & total & $454(18.4 \%)$ & $198(16.3 \%)$ & $256(20.5 \%)$ \\
\hline & $40 \sim 49$ age group & $199(24.8 \%)$ & $82(20.0 \%)$ & $117(30.0 \%)$ \\
\hline & $50 \sim 59$ age group & $97(18.1 \%)$ & $48(18.2 \%)$ & $49(8.1 \%)$ \\
\hline & $60 \sim 69$ age group & $102(14.9 \%)$ & $46(13.8 \%)$ & $56(16.0 \%)$ \\
\hline & $70 \sim 79$ age group & $56(12.6 \%)$ & $22(10.7 \%)$ & $34(14.3 \%)$ \\
\hline & & $\mathrm{p}<0.0001^{* * *}$ & $\mathrm{p}=0.0010^{* *}$ & $\mathrm{p}<0.0001^{* * *}$ \\
\hline \multirow[t]{6}{*}{ Financial } & total & $391(15.9 \%)$ & $189(15.6 \%)$ & $202(16.2 \%)$ \\
\hline & $40 \sim 49$ age group & $167(20.8 \%)$ & $81(19.7 \%)$ & $86(22.1 \%)$ \\
\hline & $50 \sim 59$ age group & $97(18.1 \%)$ & $46(17.4 \%)$ & $51(18.8 \%)$ \\
\hline & $60 \sim 69$ age group & $90(13.2 \%)$ & $47(14.1 \%)$ & $43(12.3 \%)$ \\
\hline & $70 \sim 79$ age group & $37(8.3 \%)$ & $15(7.3 \%)$ & $22(9.2 \%)$ \\
\hline & & $\mathrm{p}<0.0001^{* * *}$ & $\mathrm{p}<0.0001^{* * *}$ & $\mathrm{p}<0.0001^{* * *}$ \\
\hline \multirow[t]{6}{*}{ At workplace or job } & total & $457(18.5 \%)$ & $281(23.1 \%)$ & $176(14.1 \%)$ \\
\hline & $40 \sim 49$ age group & $245(30.6 \%)$ & $144(35.0 \%)$ & $101(25.9 \%)$ \\
\hline & $50 \sim 59$ age group & $121(22.6 \%)$ & $79(29.9 \%)$ & $42(15.5 \%)$ \\
\hline & $60 \sim 69$ age group & $64(9.4 \%)$ & $42(12.6 \%)$ & $22(6.3 \%)$ \\
\hline & $70 \sim 79$ age group & $27(6.1 \%)$ & $16(7.8 \%)$ & $11(4.6 \%)$ \\
\hline & & $\mathrm{p}<0.0001^{* * *}$ & $\mathrm{p}<0.0001^{* * *}$ & $\mathrm{p}<0.0001^{* * *}$ \\
\hline \multirow[t]{6}{*}{ In the community } & total & $247(10.0 \%)$ & $124(10.2 \%)$ & $123(9.8 \%)$ \\
\hline & $40 \sim 49$ age group & $108(13.5 \%)$ & $54(13.1 \%)$ & $54(13.8 \%)$ \\
\hline & $50 \sim 59$ age group & $70(13.1 \%)$ & $35(13.3 \%)$ & $35(12.9 \%)$ \\
\hline & $60 \sim 69$ age group & $45(6.6 \%)$ & $21(6.3 \%)$ & $24(6.9 \%)$ \\
\hline & $70 \sim 79$ age group & $24(5.4 \%)$ & $14(6.8 \%)$ & $10(4.2 \%)$ \\
\hline & & $\mathrm{p}<0.0001^{* * *}$ & $\mathrm{p}=0.0008^{* * *}$ & $\mathrm{p}<0.0001^{* * *}$ \\
\hline \multirow[t]{6}{*}{ Environmental } & total & $241(9.8 \%)$ & $128(10.5 \%)$ & $113(9.0 \%)$ \\
\hline & $40 \sim 49$ age group & $90(11.2 \%)$ & $49(11.9 \%)$ & $41(10.5 \%)$ \\
\hline & $50 \sim 59$ age group & $45(8.4 \%)$ & $23(8.7 \%)$ & $22(8.1 \%)$ \\
\hline & $60 \sim 69$ age group & $69(10.1 \%)$ & $37(11.1 \%)$ & $32(9.1 \%)$ \\
\hline & $70 \sim 79$ age group & $37(8.3 \%)$ & $19(9.2 \%)$ & $18(7.6 \%)$ \\
\hline & & $\mathrm{p}=0.1699$ & $\mathrm{p}=0.4311$ & $\mathrm{p}=0.2691$ \\
\hline \multirow[t]{6}{*}{ Others } & total & $199(8.1 \%)$ & $102(8.4 \%)$ & $97(7.8 \%)$ \\
\hline & $40 \sim 49$ age group & $87(10.9 \%)$ & $43(10.5 \%)$ & $44(11.3 \%)$ \\
\hline & $50 \sim 59$ age group & $54(10.1 \%)$ & $30(11.4 \%)$ & $24(8.9 \%)$ \\
\hline & $60 \sim 69$ age group & $36(5.3 \%)$ & $21(6.3 \%)$ & $15(4.3 \%)$ \\
\hline & $70 \sim 79$ age group & $22(5.0 \%)$ & $8(3.9 \%)$ & $14(5.9 \%)$ \\
\hline & & $\mathrm{p}<0.0001^{* * *}$ & $\mathrm{p}=0.0014^{* *}$ & $\mathrm{p}=0.0009^{* * *}$ \\
\hline
\end{tabular}

Chi-square test for trend

$* * *$ : $\mathrm{p}<0.001,{ }^{* *}: \mathrm{p}<0.01, *: \mathrm{p}<0.05$. 
不良群とした。

-身体的健康感における良好群：「健康」，「まあ健康」

- 身体的健康感における不良群：「病気がち」,「病気」

・精神的健康感における良好群：「良い」，「まあ良い」

- 精神的健康感における不良群：「やや悪い,「悪い」

3）日常生活における保健習慣（Table 1,2）

日常生活における保健習慣として, Breslow の 7 つの 保健習慣 ${ }^{13}$, 14) を参考に, Table 2 に示す 7 つの項目それぞ れにおける好ましい習慣の実行の有無を質問した。

\section{（4）集計および統計学的方法}

各々の調査内容を集計し, 統計学的解析を行い検討し た。まずライフイベント, 主観的健康感の状況を集計 し, それらの総体的な状況および性・年齢層による違い を検討した（Table 3, 4)。年㱓層による違いは，傾向性の 検定 (Chi-square test for trend) で検討した。また, ライフ イベントの有無と主観的健康感の関連をクロス集計に よって検討した（Table 5)。

次に, 年齢層, ライフイベントの有無（Table 1 に掲げ たいずれかのライフイベントの有無), および主観的健 康感を説明変数として, 保健習慣点数を従属変数とし て, 性別にロジスティック回帰分析を行った（Table 6)。 保健習慣点数は, 個々の保健習慣 (Table 1,2) が好まし い状況である場合に 1 点として合計したものである。7 点満点で, 4 点以上を「良好群」, 3 点以下を「不良群」 と二分した。

最後に, ライフイベントの有無および主観的健康感を 説明変数に, 個々の保健習慣を従属変数として, 性別お
よび年齢層別にロジスティック回帰分析を行った（Table 7,8)。なお, 表中で示したオッズ比は, ライフイベント が「なかった」で，かつ主観的健康感が「良好群」に属 する場合を 1 としたときの数值である。集計および統計 学的解析には, ソフトウェア「HALBAU for Windows Ver.5.1」および「SAS-JMP Ver.4.0」を用いた。

\section{結果}

\section{1. ライフイベントの有無 (Table 3)}

全体では，最近 1 年間のライフイベントの割合は「健 康上」で「あった」者が $25.4 \%$ と高く, ついで「仕事 上」 $18.5 \%$,「家族関係」 $18.4 \%$,「経済上」 $15.9 \%$ の順 であった。性別・年齢層別では, 男女ともに「家族関 係」,「経済上」,「仕事上」「地域」および「その他」につ いて，有意な負の傾向性が認められた。また，「仕事上」 では男性で「あった」者の割合が高かった。「環境上」 では, 性および年齢層による有意差は認められなかっ た。

\section{2. 主観的健康感（Table 4）}

全体での良好群の割合は, 身体的健康感で $85.8 \%$, 精 神的健康感で $83.9 \%$, 生きがい感では $71.5 \%$ であった。 男女ともに，身体的健康感では高年歯層ほど低くなる負 の傾向が，逆に，生きがい感では高年齢層ほど高くなる 正の傾向が認められた。いずれも傾向性の検定 (Chisquare test for trend）において有意であった。精神的健康 感では性および年齢層による有意差は見られなかった。

Table 4 Subjective health status

\begin{tabular}{|c|c|c|c|c|c|c|c|}
\hline & & \multicolumn{2}{|c|}{ Total $(n=2,464)$} & \multicolumn{2}{|c|}{ Male $(n=1,215)$} & \multicolumn{2}{|c|}{ Female $(n=1,249)$} \\
\hline & & Good & Poor & Good & Poor & Good & Poor \\
\hline \multirow[t]{6}{*}{ Physical health status } & total & $2,113(85.8 \%)$ & $351(14.2 \%)$ & $1,038(85.4 \%)$ & $177(14.6 \%)$ & $1,075(86.1 \%)$ & $174(13.9 \%)$ \\
\hline & $40 \sim 49$ age group & $732(91.4 \%)$ & $69(8.6 \%)$ & $375(91.2 \%)$ & $36(8.8 \%)$ & $357(91.5 \%)$ & $33(8.5 \%)$ \\
\hline & $50 \sim 59$ age group & $474(88.6 \%)$ & $61(11.4 \%)$ & $236(89.4 \%)$ & $28(10.6 \%)$ & $238(87.8 \%)$ & $33(12.2 \%)$ \\
\hline & $60 \sim 69$ age group & $578(84.5 \%)$ & $106(15.5 \%)$ & $274(82.0 \%)$ & $60(18.0 \%)$ & $304(86.9 \%)$ & $46(13.1 \%)$ \\
\hline & $70 \sim 79$ age group & $329(74.1 \%)$ & $115(25.9 \%)$ & $153(74.3 \%)$ & $53(25.7 \%)$ & $176(73.9 \%)$ & $62(26.1 \%)$ \\
\hline & & \multicolumn{2}{|c|}{$\mathrm{p}<0.0001^{* * *}$} & \multicolumn{2}{|c|}{$\mathrm{p}<0.0001^{* * *}$} & \multicolumn{2}{|c|}{$\mathrm{p}<0.0001^{* * *}$} \\
\hline \multirow[t]{6}{*}{ Mental health status } & total & $2,067(83.9 \%)$ & $397(16.1 \%)$ & $1,015(83.5 \%)$ & $200(16.5 \%)$ & $1,052(84.2 \%)$ & $197(15.8 \%)$ \\
\hline & $40 \sim 49$ age group & $674(84.1 \%)$ & $127(15.9 \%)$ & $348(84.7 \%)$ & $63(15.3 \%)$ & $326(83.6 \%)$ & $64(16.4 \%)$ \\
\hline & $50 \sim 59$ age group & $451(84.3 \%)$ & $84(15.7 \%)$ & $226(85.6 \%)$ & $38(14.4 \%)$ & $225(83.0 \%)$ & $46(17.0 \%)$ \\
\hline & $60 \sim 69$ age group & $584(85.4 \%)$ & $100(14.6 \%)$ & $277(82.9 \%)$ & $57(17.1 \%)$ & 307 (87.7\%) & $43(12.3 \%)$ \\
\hline & $70 \sim 79$ age group & $358(80.6 \%)$ & $86(19.4 \%)$ & $164(79.6 \%)$ & $42(20.4 \%)$ & $194(81.5 \%)$ & $44(18.5 \%)$ \\
\hline & & \multicolumn{2}{|c|}{$\mathrm{p}=0.3039$} & \multicolumn{2}{|c|}{$\mathrm{p}=0.1089$} & \multicolumn{2}{|c|}{$\mathrm{p}=0.9016$} \\
\hline \multirow[t]{6}{*}{ Life satisfaction } & total & $1,762(71.5 \%)$ & $702(28.5 \%)$ & $856(70.5 \%)$ & $359(29.5 \%)$ & $906(72.5 \%)$ & $343(27.5 \%)$ \\
\hline & $40 \sim 49$ age group & $523(65.3 \%)$ & $278(34.7 \%)$ & $263(64.0 \%)$ & $148(36.0 \%)$ & $260(66.7 \%)$ & $130(33.3 \%)$ \\
\hline & $50 \sim 59$ age group & $352(65.8 \%)$ & $183(34.2 \%)$ & $173(65.5 \%)$ & $91(34.5 \%)$ & $179(66.1 \%)$ & $92(33.9 \%)$ \\
\hline & $60 \sim 69$ age group & $538(78.7 \%)$ & $146(21.3 \%)$ & $259(77.5 \%)$ & $75(22.5 \%)$ & $279(79.7 \%)$ & $71(20.3 \%)$ \\
\hline & $70 \sim 79$ age group & $349(78.6 \%)$ & $95(21.4 \%)$ & $161(78.2 \%)$ & $45(21.8 \%)$ & $188(79.0 \%)$ & $50(21.0 \%)$ \\
\hline & & \multicolumn{2}{|c|}{$\mathrm{p}<0.0001^{* * *}$} & \multicolumn{2}{|c|}{$\mathrm{p}<0.0001 * * *$} & \multicolumn{2}{|c|}{$\mathrm{p}<0.0001^{* * *}$} \\
\hline
\end{tabular}

Chi-square test for trend

$* * *: \mathrm{p}<0.001, * *: \mathrm{p}<0.01, *: \mathrm{p}<0.05$. 


\section{3. ライフイベントの有無と主観的健康感との関連}

(Table 5)

ライフイベントと主観的健康感との関連についてクロ ス集計を行った。できごとが「あった」者の割合は，主 観的健康感の不良群の方が高く，その傾向は，いずれの 主観的健康感においても同様であった。

\section{1) ライフイベントの有無と身体的健康感との関連}

身体的健康感の不良群において，できごとが「あった」 者の割合が高かったのは，全体では「健康上」が第 1 位 で，「家族関係」，「経済上」の順であった。性別では，男 性で「地域」「環境上」が女性に比べて高い割合であっ た。
2）ライフイベントの有無と精神的健康感との関連

全体の検討では前項と同様の傾向であった。性差を検 討すると，「仕事上」については男性の，「健康上」およ び「家族関係」では女性の不良群の割合が高かった。

3）ライフイベントの有無と生きがい感との関連

全体でみると，できごとが「あった」者の割合が高か ったのは，全体では「健康上」が第 1 位であり，ついで 「家族関係」，「仕事上」の順であった。性別にみると，男 性では「仕事上」および「環境上」で，女性では「健康 上」および「家族関係」で不良群の割合が高かった。

Table 5 Association between subjective health status and life events

\begin{tabular}{|c|c|c|c|c|c|c|c|c|}
\hline \multirow{2}{*}{ Life events } & & \multirow{2}{*}{ Experienced } & \multicolumn{2}{|c|}{ Physical health status } & \multicolumn{2}{|c|}{ Mental health status } & \multicolumn{2}{|c|}{ Life satisfaction } \\
\hline & & & Good & Poor & Good & Poor & Good & Poor \\
\hline \multirow[t]{6}{*}{ Health-related } & total $(n=2,464)$ & yes & $421(19.9 \%)$ & $206(58.7 \%)$ & $419(20.3 \%)$ & $208(52.4 \%)$ & $396(22.5 \%)$ & $231(32.9 \%)$ \\
\hline & & no & $1,692(80.1 \%)$ & $145(41.3 \%)$ & $1,648(79.7 \%)$ & $189(47.6 \%)$ & $1,366(77.5 \%)$ & $471(67.1 \%)$ \\
\hline & male $(\mathrm{n}=1,215)$ & yes & $171(16.5 \%)$ & $103(58.2 \%)$ & $178(17.5 \%)$ & $96(48.0 \%)$ & $168(19.6 \%)$ & $106(29.5 \%)$ \\
\hline & & no & $867(83.5 \%)$ & $74(41.8 \%)$ & $837(82.5 \%)$ & $104(52.0 \%)$ & $688(80.4 \%)$ & $253(70.5 \%)$ \\
\hline & famale $(\mathrm{n}=1,249)$ & yes & $250(23.3 \%)$ & $103(59.2 \%)$ & $241(22.9 \%)$ & $112(56.9 \%)$ & $228(25.2 \%)$ & $125(36.4 \%)$ \\
\hline & & no & $825(76.7 \%)$ & $71(40.8 \%)$ & $811(77.1 \%)$ & $85(43.1 \%)$ & $678(74.8 \%)$ & $218(63.6 \%)$ \\
\hline \multirow[t]{6}{*}{ Family } & total $(n=2,464)$ & yes & $360(17.0 \%)$ & $94(26.8 \%)$ & $309(14.9 \%)$ & $145(36.5 \%)$ & $273(15.5 \%)$ & $181(25.8 \%)$ \\
\hline & & no & $1,753(83.0 \%)$ & $257(73.2 \%)$ & $1,758(85.1 \%)$ & $252(63.5 \%)$ & $1,489(84.5 \%)$ & $521(74.2 \%)$ \\
\hline & male $(\mathrm{n}=1,215)$ & yes & $151(14.5 \%)$ & $47(26.6 \%)$ & $132(13.0 \%)$ & $66(33.0 \%)$ & $117(13.7 \%)$ & $81(22.6 \%)$ \\
\hline & & no & $887(85.5 \%)$ & $130(73.4 \%)$ & $883(87.0 \%)$ & $134(67.0 \%)$ & $739(86.3 \%)$ & $278(77.4 \%)$ \\
\hline & famale $(n=1,249)$ & yes & $209(19.4 \%)$ & $47(27.0 \%)$ & $177(16.8 \%)$ & $79(40.1 \%)$ & $156(17.2 \%)$ & $100(29.2 \%)$ \\
\hline & & no & $866(80.6 \%)$ & $127(73.0 \%)$ & $875(83.2 \%)$ & $118(59.9 \%)$ & $750(82.8 \%)$ & $243(70.8 \%)$ \\
\hline \multirow[t]{6}{*}{ Financial } & total $(n=2,464)$ & yes & $313(14.8 \%)$ & $78(22.2 \%)$ & $264(12.8 \%)$ & $127(32.0 \%)$ & $215(12.2 \%)$ & $176(25.1 \%)$ \\
\hline & & no & $1,800(85.2 \%)$ & $273(77.8 \%)$ & $1,803(87.2 \%)$ & $270(68.0 \%)$ & $1,547(87.8 \%)$ & $526(74.9 \%)$ \\
\hline & male $(n=1,215)$ & yes & $148(14.3 \%)$ & $41(23.2 \%)$ & $125(12.3 \%)$ & $64(32.0 \%)$ & $102(11.9 \%)$ & $87(24.2 \%)$ \\
\hline & & no & $890(85.7 \%)$ & $136(76.8 \%)$ & $890(87.7 \%)$ & $136(68.0 \%)$ & $754(88.1 \%)$ & $272(75.8 \%)$ \\
\hline & famale $(\mathrm{n}=1,249)$ & yes & $165(15.3 \%)$ & $37(21.3 \%)$ & $139(13.2 \%)$ & $63(32.0 \%)$ & $113(12.5 \%)$ & $89(25.9 \%)$ \\
\hline & & no & $910(84.7 \%)$ & $137(78.7 \%)$ & $913(86.8 \%)$ & $134(68.0 \%)$ & $793(87.5 \%)$ & $254(74.1 \%)$ \\
\hline \multirow[t]{6}{*}{ At workplace or job } & total $(n=2,464)$ & yes & $388(18.4 \%)$ & $69(19.7 \%)$ & $335(16.2 \%)$ & $122(30.7 \%)$ & $277(15.7 \%)$ & $180(25.6 \%)$ \\
\hline & & no & $1,725(81.6 \%)$ & $282(80.3 \%)$ & $1,732(83.8 \%)$ & $275(69.3 \%)$ & $1,485(84.3 \%)$ & $522(74.4 \%)$ \\
\hline & male $(n=1,215)$ & yes & $236(22.7 \%)$ & $45(25.4 \%)$ & $205(20.2 \%)$ & $76(38.0 \%)$ & $159(18.6 \%)$ & $122(34.0 \%)$ \\
\hline & & no & $802(77.3 \%)$ & $132(74.6 \%)$ & $810(79.8 \%)$ & $124(62.0 \%)$ & $697(81.4 \%)$ & $237(66.0 \%)$ \\
\hline & famale $(\mathrm{n}=1,249)$ & yes & $152(14.1 \%)$ & $89(25.9 \%)$ & $130(12.4 \%)$ & $46(23.4 \%)$ & $118(13.0 \%)$ & $58(16.9 \%)$ \\
\hline & & no & $923(85.9 \%)$ & $254(74.1 \%)$ & $922(87.6 \%)$ & $151(76.6 \%)$ & $788(87.0 \%)$ & $285(83.1 \%)$ \\
\hline \multirow[t]{6}{*}{ In the community } & total $(n=2,464)$ & yes & $207(9.8 \%)$ & $40(11.4 \%)$ & $175(8.5 \%)$ & $72(18.1 \%)$ & $138(7.8 \%)$ & $109(15.5 \%)$ \\
\hline & & no & $1,906(90.2 \%)$ & $311(88.6 \%)$ & $1,892(91.5 \%)$ & $325(81.9 \%)$ & $1,624(92.2 \%)$ & $593(84.5 \%)$ \\
\hline & male $(n=1,215)$ & yes & $100(1.1 \%)$ & $24(13.6 \%)$ & $87(8.6 \%)$ & $37(18.5 \%)$ & $65(7.6 \%)$ & $59(16.4 \%)$ \\
\hline & & no & $9,358(98.9 \%)$ & $153(86.4 \%)$ & $928(91.4 \%)$ & $163(81.5 \%)$ & $791(92.4 \%)$ & $300(83.6 \%)$ \\
\hline & famale $(n=1,249)$ & yes & $107(10.0 \%)$ & $16(9.2 \%)$ & $88(8.4 \%)$ & $35(17.8 \%)$ & $73(8.1 \%)$ & $50(14.6 \%)$ \\
\hline & & no & $968(90.0 \%)$ & $158(90.8 \%)$ & $964(91.6 \%)$ & $162(82.2 \%)$ & $833(91.9 \%)$ & $293(85.4 \%)$ \\
\hline \multirow[t]{6}{*}{ Environmental } & total $(n=2,464)$ & yes & $195(9.2 \%)$ & $46(13.1 \%)$ & $184(8.9 \%)$ & $57(14.4 \%)$ & $154(8.7 \%)$ & $87(12.4 \%)$ \\
\hline & & no & $1,918(90.8 \%)$ & $305(86.9 \%)$ & $1,883(91.1 \%)$ & $340(85.6 \%)$ & $1,608(91.3 \%)$ & $615(87.6 \%)$ \\
\hline & male $(n=1,215)$ & yes & $102(9.8 \%)$ & $26(14.7 \%)$ & $98(9.7 \%)$ & $30(15.0 \%)$ & $76(8.9 \%)$ & $52(14.5 \%)$ \\
\hline & & no & $936(90.2 \%)$ & $151(85.3 \%)$ & $917(90.3 \%)$ & $170(85.0 \%)$ & $780(91.1 \%)$ & $307(85.5 \%)$ \\
\hline & famale $(\mathrm{n}=1,249)$ & yes & $93(8.7 \%)$ & $20(11.5 \%)$ & $86(8.2 \%)$ & $27(13.7 \%)$ & $78(8.6 \%)$ & $35(10.2 \%)$ \\
\hline & & no & $982(91.3 \%)$ & $154(88.5 \%)$ & $966(91.8 \%)$ & $170(86.3 \%)$ & $828(91.4 \%)$ & $308(89.8 \%)$ \\
\hline \multirow[t]{6}{*}{ Others } & total $(n=2,464)$ & yes & $158(7.5 \%)$ & $41(11.7 \%)$ & $138(6.7 \%)$ & $61(15.4 \%)$ & $115(6.5 \%)$ & $84(12.0 \%)$ \\
\hline & & no & $1,955(92.5 \%)$ & $310(88.3 \%)$ & $1,929(93.3 \%)$ & $336(84.6 \%)$ & $1,647(93.5 \%)$ & $618(88.0 \%)$ \\
\hline & male $(\mathrm{n}=1,215)$ & yes & $80(7.7 \%)$ & $22(12.4 \%)$ & $68(6.7 \%)$ & $34(17.0 \%)$ & $53(6.2 \%)$ & $49(13.6 \%)$ \\
\hline & & no & $958(92.3 \%)$ & $155(87.6 \%)$ & $947(93.3 \%)$ & $166(83.0 \%)$ & $803(93.8 \%)$ & $310(86.4 \%)$ \\
\hline & famale $(n=1,249)$ & yes & $78(7.3 \%)$ & $19(10.9 \%)$ & $70(6.7 \%)$ & $27(13.7 \%)$ & $62(6.8 \%)$ & $35(10.2 \%)$ \\
\hline & & no & $997(92.7 \%)$ & $155(89.1 \%)$ & $982(93.3 \%)$ & $170(86.3 \%)$ & $844(93.2 \%)$ & $308(89.8 \%)$ \\
\hline
\end{tabular}


4. ライフイベントの有無と主観的健康感，保健習慣との ラ関連（Table 6-8）

男性では生きがい感（不良群）が，女性ではライフイ ベントの有無（あった）が保健習慣点数（不良群）と強 い関連があった。また，男女ともに年齢は保健習慣点数 と負の関連を示した。

次に，個々の保健習慣に対する，ライフイベントの有 無および主観的健康感との関連を検討するため, 性別お よび年齢層別に解析を行った（Table 7, 8)。いくつかの 保健習慣においては，ライフイベント「あった」で主観 的健康感が不良な者のオッズ比が特に高かった。とりわ け「体重の変化」では, 男女ともにこの傾向が強かった。 同様の傾向が見られた保健習慣は，男性の中年齢層にお ける「運動習慣」および高年齢層の「睡眠時間」，また女 性の中年齢層における「睡眠時間」, 高年齢層の「朝食の 摂取」および「睡眠時間」であった。

なお，男性の高年齢層の「喫煙習慣」は，主観的健康 感の状況およびライフイベントの有無と負の関連を示し た。また一方で, ライフイベントは「なし」で主観的健 康感が不良な者でのオッズ比が最も高い保健習慣があっ た。この傾向は, 男性では中年齢層の「過度の飲酒」お よび高年齢層の「運動習慣」において，女性では中年齢 層の「朝食の摂取」および高年齢層の「運動習慣」にお いて見られた。男性の高年齢層における「喫煙」では,
いずれの主観的健康感においても負の関連を示した。

\section{考察}

総体的に男女とも，主観的健康感の状況から，加齢に 伴って身体的機能は低下し, 疾病罪患のリスクは増加す るにもかかわらず，精神的健康感は低下しにくい15) こ と，また良好な生きがい感を得ている者が多いことがう かがわれた。その要因の一つとして, 今回の調查対象地 域が，自治会組織や農作業などを機縁とする地縁的結合 が強く, 高齢者の社会参加の役割が比較的多い地域で あったことが考えられる。

ライフイベントの有無と主観的健康感の関連をみる と，男女とも，ライフイベントを経験した者において主 観的健康感がより不良である傾向を示し，ストレス要因 としてのライフイベントの影響が確認された。性別の検 討では, 男性は「仕事上」，女性は「家族関係」のできご とが主観的健康感との関連が強かった。これは先行研 究 ${ }^{10)}$ における知見と同様であったが，さらに本研究で は，男女ともに「地域」のできごととの関連性を初めて 指摘できた。具体的にどのような「地域」のできごとが ストレス要因として影響を及ぼす可能性があるのか, 調 査・検討の必要がある。

Table 7 および Table 8 では,「体重の変化」のように,

Table 6 Association between subjective health status and health practices using logistic regression analysis

\begin{tabular}{|c|c|c|c|}
\hline \multirow{2}{*}{ Male } & \multicolumn{3}{|c|}{ Health behaviors score (by Breslow): $\geqq 4, \leqq 3$} \\
\hline & Regression coefficient & $\mathrm{p}$ value & OR $(95 \% \mathrm{CI})$ \\
\hline \multicolumn{4}{|l|}{ Age: } \\
\hline$<60$ years, $\geqq 60$ years & -0.431 & $<0.001$ & $0.42(0.28-0.63)^{* * *}$ \\
\hline \multicolumn{4}{|l|}{ Life events: } \\
\hline not experienced, experienced & 0.079 & 0.402 & $1.17(0.81-1.70)$ \\
\hline \multicolumn{4}{|l|}{ Physical health status: } \\
\hline good, poor & 0.033 & 0.823 & $1.07(0.59-1.87)$ \\
\hline \multicolumn{4}{|l|}{ Mental health status: } \\
\hline good, poor & 0.189 & 0.151 & $1.46(0.86-2.42)$ \\
\hline \multicolumn{4}{|l|}{ Life satisfaction: } \\
\hline good, poor & 0.204 & 0.037 & $1.50(1.02-2.20)^{*}$ \\
\hline
\end{tabular}

\begin{tabular}{|c|c|c|c|}
\hline \multirow{2}{*}{ Female } & \multicolumn{3}{|c|}{ Health behaviors score (by Breslow): $\geqq 4, \leqq 3$} \\
\hline & Regression coefficient & $\mathrm{p}$ value & OR $(95 \% \mathrm{CI})$ \\
\hline \multicolumn{4}{|l|}{ Age: } \\
\hline$<60$ years, $\geqq 60$ years & -0.693 & $<0.001$ & $0.25(0.13-0.45)^{* * *}$ \\
\hline \multicolumn{4}{|l|}{ Life events: } \\
\hline not experienced, experienced & 0.258 & 0.047 & $1.67(1.01-2.81)^{*}$ \\
\hline \multicolumn{4}{|l|}{ Physical health status: } \\
\hline good, poor & 0.239 & 0.187 & $1.61(0.77-3.22)$ \\
\hline \multicolumn{4}{|l|}{ Mental health status: } \\
\hline good, poor & 0.049 & 0.776 & $1.10(0.55-2.11)$ \\
\hline \multicolumn{4}{|l|}{ Life satisfaction: } \\
\hline good, poor & 0.151 & 0.236 & $1.35(0.81-2.22)$ \\
\hline
\end{tabular}

Logistic regression was performed.

$* * *: \mathrm{p}<0.001,{ }^{* *}: \mathrm{p}<0.01,{ }^{*}: \mathrm{p}<0.05$. 


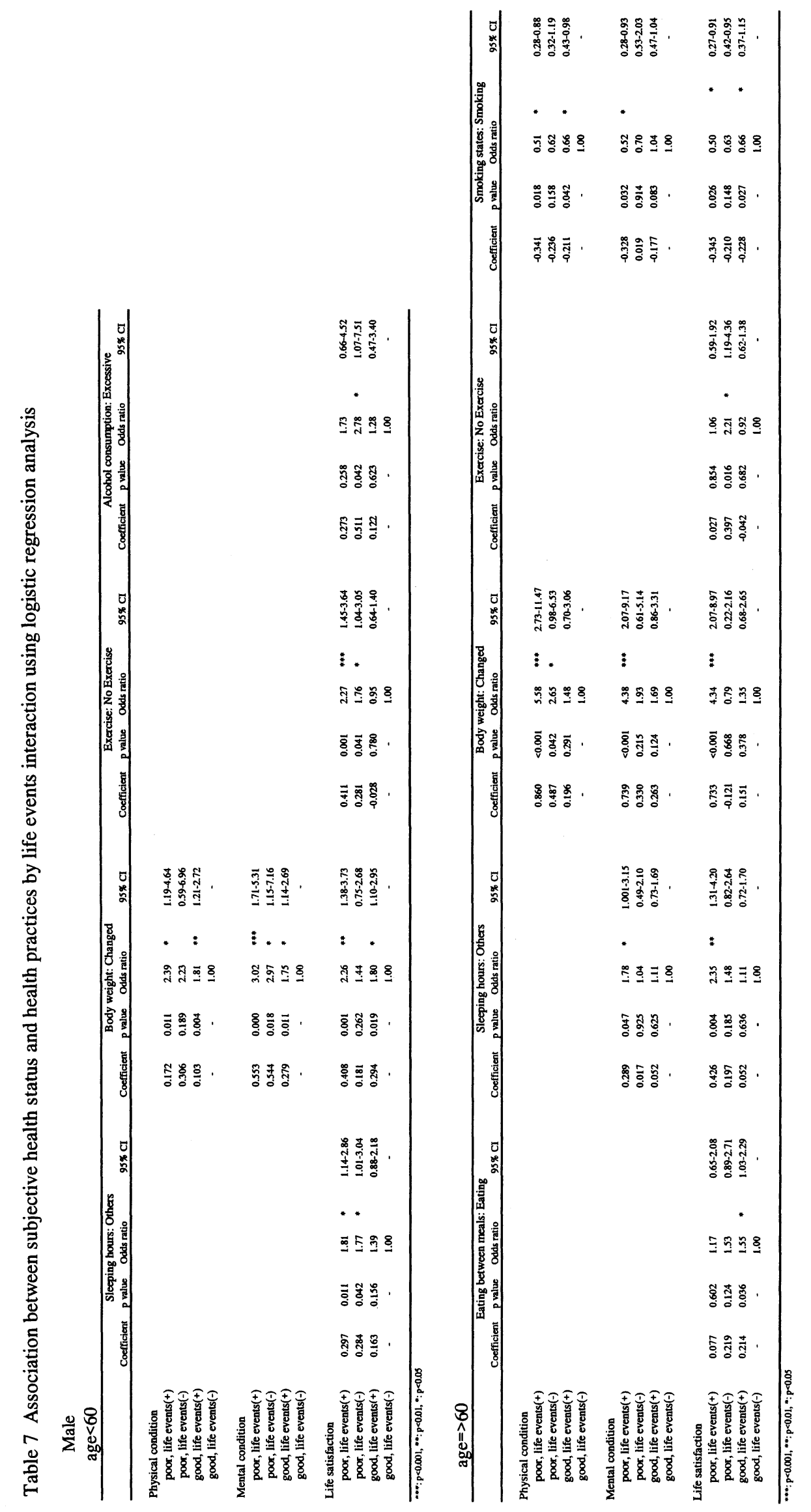


日衛誌 (Jpn. J. Hyg.) 第 56 巻 第 2 号 2001 年 7 月

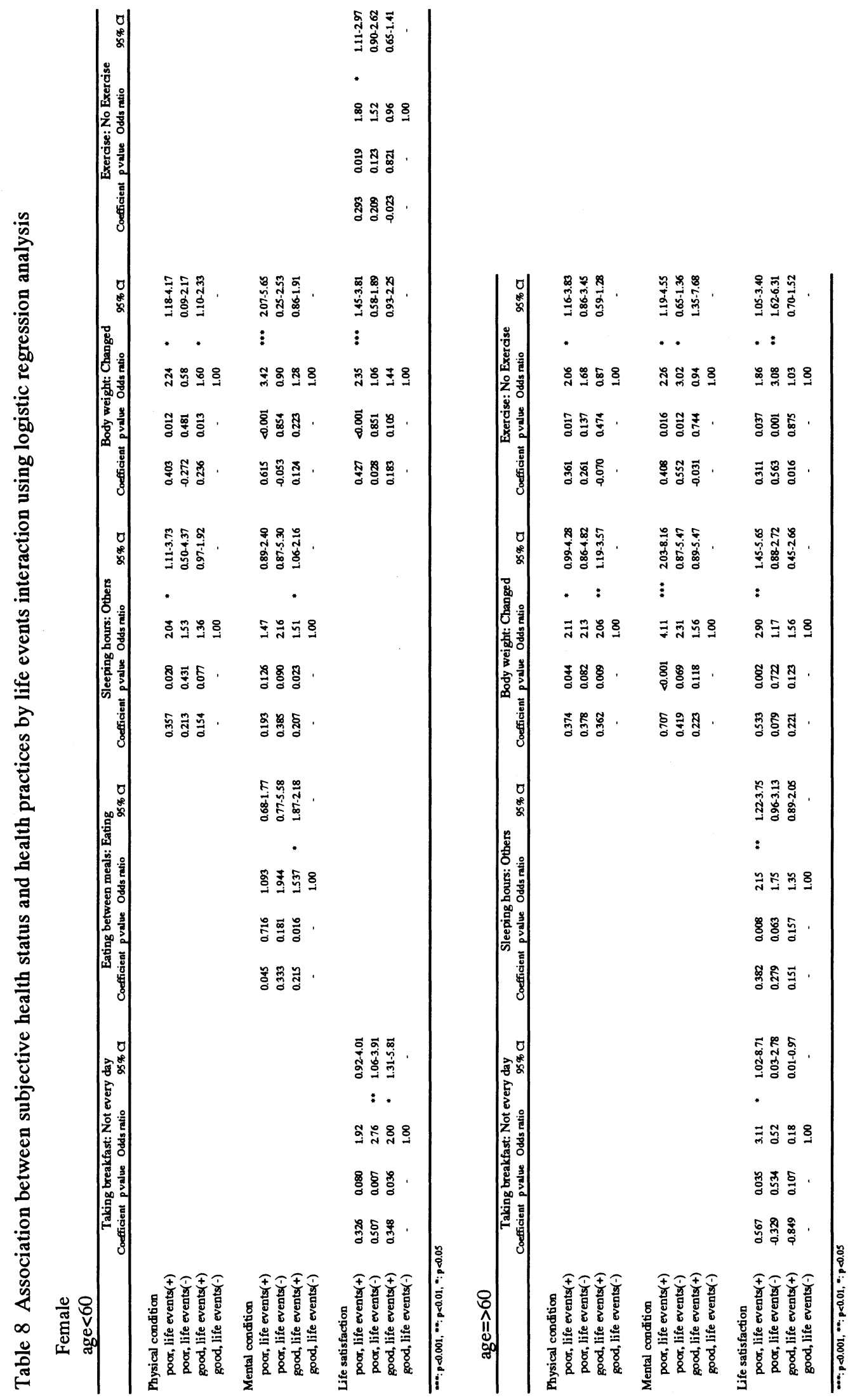


「ライフイベントがあり，かつ主観的健康感が不良」群 で最も強い関連を示す保健習慣が見られた。これは，ラ イフイベントと主観的健康感が保健習慣に対して何らか の相互作用的な関連を持っている可能性を示唆する結果 であった。一方で，女性の中年齢層における「朝食の摂 取」のように，「ライフイベントはなかったが，生きが い感は不良」群で最も強い関連を示す保健習慣が見られ た。これは単に性・年齢による違いではなく, 日常いら だち事 (daily hassles) など，ライフイベント以外のスト レス要因 ${ }^{16)}$ や抑うつ状態の有無 ${ }^{17)}$ などを考慮に入れる 必要を示していると考えられる。しかし，今回の調査票 の質問内容からは，これ以上の検討を行うことはできな かった。

なお，調查票の回収率は $80.8 \%$ であったが，有効回答 率は $61.4 \%$ とやや低かった。しかし全回答者による集計 でも，各々の質問項目における回答内容の分布は，性・ 年齢層別の集計でもほぼ同様の状況であった。ただし 今回の調査では，医療機関その他施設等に長期入院（入 所）している者からは回答を得られなかった。また，寝 たきり者および虚弱者の中には，本調査に回答していな い者が含まれている可能性がある。このため, 調査の段 階における選択的バイアスが生じている可能性は考慮し なければならない。

主観的健康感はその地域の持つ文化社会的背景や社会 的価值観といった要因を考慮して慎重に用いるべきであ

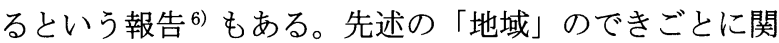
する問題点も含めて，具体的にどのようなストレス要因 が保健習慣に対する関連や影響を持っているのか，今後 さらに調査・検討していきたい。

\section{文献}

1）佐藤秀紀, 中嶋和夫, 安西将也, 西田美佐, 福渡 靖. 高齢者の健康観に関連する要因. 厚生の指標 44:3-9, 1997.

2）大野 裕, 吉村公雄, 山内慶太, 百瀬知雄, 水島広子, 浅井昌弘．心理的健康感と心理的不健康感の関係に ついて 患者群と非患者群の比較。ストレス科学 10： 273-278, 1995.
3) Maddox GL, Douglass EB. Self assessment of health: a longitudinal study of elderly subjects. J Health Soc Behav 14: 87-93, 1973.

4) Mossey JM, Shapiro E. Self-rated health: a predictor of mortality among the elderly. Am J Public Health 72: 800808, 1982

5) Segovia J, Bartlett RF, Edwards AC. An empirical analysis of the dimensions of health status measures. Soc Sci Med 29: 761-768, 1989.

6）藤田利治，籏野脩一. 地域老人の健康度自己評価の関 連要因とその後 2 年間の死亡. 社会老年学 $31: 43-51$, 1986

7）杉澤秀博．高齢者における健康度自己評価の関連要因 に関する研究一質的・統計的解析に基づいて一. 社会 老年学 38: 13-23, 1993.

8）杉澤秀博，Liang J. 高齢者における健康度自己評価と 日常生活動作能力の予後との関係．社会老年学 39：310, 1994.

9）芳賀 博，松崎俊久，籏野脩一，老人の保健行動．社 会老年学 15：64-73，1984.

10）土屋八千代，上畑鉄之丞，関谷栄子，阿部真雄，石原 伸哉, 及川しほ, 千田忠男, 山崎喜比古, 杉澤あつ子, 坂野純子, 長谷川吉則. 日本の産業労働者の Life Events に関する研究。日衛誌 49：578-587，1994.

11) Blazer DG, Houpt J. Perception of poor health in the healthy older adult. J Am Getriatr Soc 27 : 330-334, 1979.

12）實成文彦，浅川冨美雪，後藤敦，赤木京子, 竹内由美, 長谷場涼子.日常生活レベルでとらえた肉体的, 精神 的, 社会的健康の認識について. 四国公衛誌 31：68-77, 1986.

13) Belloc NB, Breslow L. Relationship of physical health status and health practices. Prev Med 1: 409-421, 1972.

14) Belloc NB. Relationship of health practices and mortality Prev Med 2: 67-81, 1973.

15）森本兼显. ライフスタイルと健康 1 . 身体的健康度と精 神的健康度. 公衆衛生 51：135-143，1987.

16）中川裕子，高林 弘，高橋進吾，多田羅浩三．都市住 民の主観的ストレスと健康指標に関する調査研究一大 阪府 $\mathrm{S}$ 市基本健康診査受診者の男女別・年齢別検討一。 日衛誌 53: 407-419, 1998.

17）宮地尚子，東あかね，小笹晃太郎，渡辺能行，青池 是，川井啓市．農村住民における抑うつと一般健康状 態および生活習慣. 日公衛誌 41：452-460，1994. 